\title{
PENGEMBANGAN PERANGKAT PEMBELAJARAN MODEL THINK TALK WRITE SUBTEMA HIDUP RUKUN UNTUK MENINGKATKAN KEMAMPUAN BERPIKIR KRITIS SISWA KELAS V SEKOLAH DASAR
}

\author{
Zera Dristya Caitra $^{1}$, Nasution ${ }^{2}$, Wahyu Sukartiningsih ${ }^{3}$ \\ ${ }^{1}$ Mahasiswa Program Pascasarjana, Prodi Pendidikan Dasar, Universitas Negeri Surabaya, \\ ${ }^{2 \& 3}$ Dosen Pascasarjana, Prodi Pendidikan Dasar, Universitas Negeri Surabaya \\ e-mail: zeya_22@yahoo.com
}

\section{Received : $\quad$ Maret 2019}

Reviewed : April 2019

Accepted : $\quad$ Mei 2019

Published : Mei 2019

\section{ABSTRACT}

This research aimed to develop Think Talk Write (TTW) model learning set and describe the process of harmonious life subtheme learning set development. This is a developmental research based on Thiagarajan's Four-D model development which consist of the following stages: (1) define, (2) design, (3) develop, and (4) disseminate. However, this research was limited to development stage only, no dissemination. The research design applied was Pretest-Posstest Control Group Design. The learning set developed covered lesson plan (RPP) Student Learning Material (BAS), Student Workseet (LKS), and critical thinking ability test which was tried out to 35 students of class VA and 35 students of class VB at SDN Wonocolo II Sidoarjo. The validation of the learning set was done by two validators experts, covering lesson plam (RPP) which gained average score 3.12, Student Learning Material (BAS) validation result was in average of 3.0, Student Workseet (LKS) validation result was 3.20 in average, and the validation result of critical thinking ability average 3.1 with valid overall category. The result of learning set based on the average score of lesson plan implementatiom which was in good category. The result $f$ observation on students' acitivities during the teaching learning process showed that they were active and were in good category. The students' response towards the teaching learning process was $80 \%$ which indicated that they studied actively and gave positive response. The test on the hypothesis which was analyzed with T-test showed that students' learning result in experimental group was higher than those of control group. It showed by the value of $\mathrm{t}_{\mathrm{count}}(0.52)>\mathrm{t}_{\mathrm{table}}(1.667)$ and $65.7 \%$ for the experimental group and $60 \%$ fot the contol group. Therefore, it can be concluded that the Think Talk Write (TTW) mode learning set validation result showed valid category and effective to be used to improve the critical thinking ability of V grade students of SDN Wonocolo II Sidoarjo.

Keywords: The Development of Learning Device, Think Talk Write, Critical Thinking.

\section{ABSTRAK}

Penelitian ini bertujuan untuk mengembangkan perangkat pembelajaran model Think Talk Write (TTW) dan mendeskripsikan proses pengembangan perangkat pembelajaran subtema hidup rukun. Penelitian ini termasuk penelitian pengembangan yang berdasarkan pada pengembangan model Four-D oleh Thiagarajan yang terdiri atas tahap: (1) pendefinisian, (2) perancangan, (3) pengembangan, dan (4) penyebaran. Akan tetapi, penelitian ini hanya sampai pada tahap pengembangan tanpa melakukan tahap penyebaran produk. Rancangan pada penelitian ini adalah Pretest-Posstest Control Group Design. Perangkat pembelajaran yang dikembangkan meliputi Rencana Pelaksanaan Pembelajaran (RPP), Bahan Ajar Siswa (BAS), Lembar Kegiatan Siswa (LKS), dan Tes Kemampuan Berpikir Kritis siswa yang diujicobakan pada kelas VA berjumlah 35 siswa dan kelas VB berjumlah 35 siswa di SDN Wonocolo II Sidoarjo. Validasi perangkat pembelajaran dilakukan 
oleh dua orang validator/ahli, meliputi Rencana Pelaksanaan Pembelajaran (RPP) diperoleh nilai rata-rata 3.12, hasil validasi Bahan Ajar Siswa (BAS) diperoleh nilai rata-rata 3.0, hasil validasi Lembar Kerja Siswa (LKS) diperoleh nilai rata-rata 3.20, hasil validasi Tes Hasil Kemampuan Berpikir Kritis diperoleh rata-rata 3.0 dan hasil validasi Kemampuan Berpikir Kritis diperoleh nilai rata-rata 3.1 dengan kategori keseluruhan adalah valid. Hasil nilai rata-rata keterlaksanaan RPP berkategori baik. Hasil pengamatan aktivitas siswa selama kegiatan belajar mengajar berlangsung menunjukkan bahwa siswa belajar aktif dan berkategori baik. Hasil respon siswa terhadap kegiatan pembelajaran diperoleh rata-rata $>80 \%$ yang menunjukkan bahwa siswa belajar aktif dan siswa memberi respon positif. Sedangkan untuk pengujian hipotesis yang dianalisa dengan uji t menunjukkan bahwa hasil belajar siswa pada kelas eksperimen lebih tinggi daripada kelas kontrol. Hal ini ditunjukkan dengan nilai $\mathrm{t}_{\text {hitung }}(0.52)>\mathrm{t}_{\text {tabel }}(1,667)$ dengan presentase kelas eksperimen sebesar $65,7 \%$ dan kelas kontrol sebesar $60 \%$. Sehingga dapat disimpulkan bahwa hasil validasi perangkat pembelajaran model Think Talk Write (TTW) menunjukkan kategori valid dan efektif digunakan untuk meningkatkan kemampuan berpikir kritis siswa kelas V SDN Wonocolo II Sidoarjo.

Kata Kunci: Pengembangan Perangkat Pembelajaran, Think Talk Write, Berpikir Kritis.

\section{PENDAHULUAN}

Perkembangan suatu bangsa erat sekali hubungannya dengan masalah pendidikan. Untuk menjadi suatu bangsa yang maju harus memiliki Sumber Daya Manusia (SDM) yang berkualitas. Pendidikan merupakan wadah yang tepat untuk menciptakan manusia yang berkualitas, karena pada hakekatnya pendidikan tidak dapat dipisahkan dari kehidupan manusia. Pada perkembangan zaman sekarang ini, pendidikan di Indonesia mengalami masalah yang serius dalam peningkatan mutu pendidikan di segala jenjang, baik pendidikan formal maupun nonformal menjadi wacana yang ramai dibicarakan dan menjadi sorotan tajam di kalangan masyarakat pada umumnya, terutama di kalangan dunia pendidikan. Sorotan tersebut mengenai berbagai aspek kehidupan yang tertuang di berbagai media cetak maupun media elektronik. Selain melalui media, para pengamat pendidikan dan pengamat sosial berbicara mengenai persoalan pendidikan di Negara kita di berbagai forum seminar di tingkat lokal, nasional maupun internasional.

Dalam kegiatan pembelajaran, diperlukan adanya interaksi antara guru dengan murid. Guru bisa dikatakan mempunyai peran penting untuk mengimplementasikan perangkat pembelajaran. Namun pembelajaran saat ini dipandang sebagai subjek yang berkembang melalui pengalaman belajar sedangkan guru lebih berperan sebagai fasilitator dan motivator belajar bagi peserta didik, membantu, dan memberikan kemudahan agar peserta didik mendapatkan pengalaman belajar sesuai dengan kemampuannya serta dapat meningkatkan kemampuan berpikir kritis mereka. Namun yang terjadi, banyak guru yang mendominasi kegiatan pembelajaran sehingga peserta didik kurang terlibat partisipasinya dan kurang mendapatkan pengalaman selama proses pembelajaran berlangsung.

Keaktifan siswa juga dipengaruhi oleh guru dalam memberikan pembelajaran yang dapat dilihat selama kegiatan pembelajaran berlangsung. Oleh karena itu, diperlukan pembelajaran yang sesuai dan mampu menghubungkan materi ajar dengan hal-hal nyata dalam kehidupan sehari-hari serta mampu membuat peserta didik aktif mengkronstruksi sendiri pengetahuannya, sehingga pembelajaran bermakna akan didapatnya secara alamiah. Dalam proses pembelajaran, pengenalan terhadap diri siswa atau kepribadian diri merupakan hal yang sangat penting dalam upaya-upaya pemberdayaan diri. Pengenalan terhadap diri siswa berarti pula mengenal kelebihankelebihan untuk mencapai tujuan pembelajaran yang diharapkan. Pada sisi lain juga harus mengenal kelemahankelemahan yang ada pada diri siswa sehingga dapat berupaya untuk mengatasi kelemahan-kelemahan tersebut dengan solusi yang tepat.

Menurut Skiffington \& Zeus (dalam Griffiths, 2005) "Studies consistently outline the various nature of learning within the coaching process, generating a transfer of learning in which theoretical learning is practically applied and integrated into the minds and actions of clients" (Studi secara konsisten menguraikan berbagai sifat pembelajaran dalam proses pembinaan, menghasilkan transfer belajar dimana belajar praktis teoritis diterapkan dan diintegrasikan ke dalam pikiran dan tindakan klien). 
Kemampuan berpikir merupakan sekumpulan kemampuan yang kompleks yang dapat dilatih sejak usia dini (Suryabrata, 2002:54). Suatu proses dalam menarik suatu kesimpulan pengetahuan disebut penalaran. Berpikir bernalar, merupakan suatu bentuk kegiatan akal/ratio manusia dengan mana pengetahuan yang kita terima melalui panca indera diolah dan ditujukan untuk mencapai suatu kebenaran. Aktivitas berpikir adalah dialog dengan diri sendiri dalam batin manifestasinya ialah mempertimbangkan, merenungkan, menganalisis, menunjukkan alasan-alasan, membuktikan sesuatu, menggolong-golongkan, membanding-bandingkan, menarik kesimpulan, meneliti suatu jalan pikiran, mencari kausalitasinya, membahas secara realitas dan lain-lain. Di dalam aktivitas berpikir itulah ditunjukkan dalam logika wawasan berpikir yang tepat atau ketepatan pemikiran kebenaran berpikir yang sesuai dengan penglogisan logika yang disebut berpikir logis.

Pendidikan dengan menerapkan model pembelajaran termasuk penting, dimaksudkan agar tujuan pembelajaran dapat tercapai dalam hal perbaikan pembelajaran, artinya sebagai penyeimbang kecakapan antara kognitif dan psikomotor siswa. Menerapkan model pembelajaran yang optimal adalah inti dari sebuah proses pembelajaran dalam mencapai tujuan pembelajaran yang diinginkan. Selain itu, model pembelajaran merupakan salah satu alternatif yang dapat dipilih guru untuk melatih dan memberdayakan kemampuan berpikir kritis siswa.

Pemilihan model pembelajaran harus didasarkan pada analisis kondisi dari hasil pembelajaran di kelas. Setelah menentukan model pembelajaran kemudian diimplementasikan ke dalam perangkat pembelajaran yang dijadikan sebagai pedoman guru selama kegiatan belajar mengajar.Semua model pembelajaran memiliki dasar teori yang kokoh karena para penemunya menyajikan kita alasan yang menjelaskan mengapa kita harus menggunakan model-model ini untuk mencapai tujuan-tujuan pembelajaran yang telah dirancang. Model-model yang terpilih juga memiliki sejarah yang panjang dan telah disaring melalui pengaaman-pengalaman yang teruji (Joyce, 2009:30)

Melalui model Think Talk Write, peniliti berkeyakinan dapat meningkatkan kemampuan berpikir kritis siswa, dikarenakan model ini memasukkan unsur modalitas belajar siswa ke dalam proses pembelajaran yang dimana "Think" itu sendiri sudah termasuk dalam kegiatan berpikir. Selain itu, model Think Talk Write ini memberikan keluasaan guru dan siswa dalam menggali potensi yang ada dalam dirinya dengan mengkonstruksi ide masing-masing secara sistematis.
Perangkat pembelajaran dirancang agar dapat mendampingi guru dan dapat dijadikan pedoman guru dalam kegiatan belajar mengajar. Konsep pembelajaran dengan berpedoman pada perangkat pembelajaran dimaksudkan agar dapat menciptakan aktivitas belajar yang bermakna, yaitu mengaktualisasikan seluruh potensi yang telah dimiliki siswa dengan menekankan pembelajaran subtema hidup rukun. Pembelajaran dengan berpedoman pada perangkat pembelajaran, guru dapat menyelesaikan dan mencapai tujuan pembelajaran yang telah ditetapkan sebelumnya sekaligus sebagai sumber pengaplikasian model Think Talk Write ke dalam proses pembelajaran.

Berdasarkan uraian latar belakang di atas, maka peneliti bertujuan untuk mengembangkan perangkat pembelajaran model Think Talk Write dengan harapan dapat meningkatkan kemampuan berpikir kritis peserta didik dengan melaksanakan penelitian yang berjudul "Pengembangan Perangkat Pembelajaran Model Think Talk Write Subtema Hidup Rukun untuk Meningkatkan Kemampuan Berpikir Kritis Siswa Kelas V Sekolah Dasar".

\section{TINJAUAN PUSTAKA}

\section{Perangkat Pembelajaran}

Perangkat pembelajaran adalah kompetensi yang merujuk pada perbuatan yang bersifat rasional dan memenuhi spesifikasi tertentu dalam proses belajar. Perangkat pembelajaran dalam penelitian ini adalah sekumpulan sumber belajar yang dapat menigngkatkan pengembangan siswa dan guru saat melakukan kegiatan pembelajaran. Perangkat pembelajaran berfungsi membantu dan memudahkan guru dalam melaksanakan kegiatan pembelajaran serta mencapai tujuan yang telah dirumuskan.

Menurut Ibrahim (2002:3) perangkat pembelajaran yang diperlukan dalam mengelola proses belajar mengajar berupa: Bahan Ajar Siswa, Lembar Kegiatas Siswa (LKS), Rencana Pelaksanaan Pembelajaran (RPP), Evaluasi, serta Media Pembelajaran.

Perangkat pembelajaran juga merupakan pegangan guru dalam melaksanakan pembelajaran yang baik di kelas, laboratorium, dan/atau lapangan untuk setiap kompetensi dasar (Devi, 2009). Oleh karena itu, perangkat pembelajaran harus disusun secara sistematik agar peserta didik bisa memahami dan mengaitkan situasi di dunia nyata dengan materi saat pembelajaran berlangsung.

\section{Model Think Talk Write (TTW)}

Secara etimologi, think diartikan "berpikir", talk diartikan "berbicara", sedangkan write diartikan "menulis". Jadi, think talk write bisa diartikan sebagai berpikir, berbicara, dan menulis. Sedangkan strategi think talk write 
adalah sebuah pembelajaran yang dimulai dengan berpikir melalui bahan bacaan (menyimak, mengkritisi, dan alternatif solusi), hasil bacaannya dikomunikasikan dengan presentasi, diskusi, dan kemudian membuat laporan hasil presentasi.

Model pembelajaran yang diperkenalkan oleh Huinker \& Laughlin (1996:82) ini didasarkan pada pemahaman bahwa belajar adalah sebuah perilaku sosial yang dibangun melalui berpikir, berbicara, dan menulis. Alur kemajuan strategi TTW dimulai dari keterlibatan siswa dalam berpikir atau berdialog dengan dirinya sendiri setelah proses membaca. Selanjutnya, berbicara dan membagi ide (sharing) dengan temannya sebelum menulis. Suasana seperti ini lebih efektif jika dilakukan dalam kelompok heterogen dengan 3-5 siswa. Dalam kelompok ini, siswa diminta membaca, membuat catatan kecil, menjelaskan, mendengarkan dan membagi ide bersama teman kemudian mengungkapkannya melalui tulisan.

Dari pengertian di atas dapat disimpulkan bahwa model pembelajaran Think Talk Write adalah model pembelajaran yang diawali dengan kegiatan memahami permasalahan yang diberikan oleh guru dan siswa aktif dalam diskusi kelompok, kemudian siswa menulis hasil belajar yang diperolehnya dengan bahasanya sendiri. Model Think Talk Write membuat siswa mengkonstruksi pengetahuannya sendiri sehingga pemecahan masalah menjadi lebih baik dan anggota dalam kelompok saling membantu dan bertukar pikiran dalam kegiatan diskusi sehingga dapat membantu siswa memahami materi yang diberikan oleh guru. Selain itu melatih siswa untuk menuliskan hasil diskusi ke bentuk tulisan dan mengkomunikasikan ide-ide secara sistematis.

Langkah-langkah Pembelajaran Think Talk Write (TTW) sebagai berikut:

a. Guru membagikan LKS yang memuat soal yang harus dikerjakan oleh siswa serta petunjuk pelaksanaannya.

b. Peserta didik membaca masalah yang ada dalam LKS dan membuat catatan kecil secara individu tentang apa yang ia ketahui dan tidak ketahui dalam masalah tersebut. Ketika peserta didik membuat catatan kecil inilah akan terjadi proses berpikir (think) pada peserta didik. Setelah itu peserta didik berusaha untuk menyelesaikan masalah tersebut secara individu. Kegiatan ini bertujuan agar peserta didik dapat membedakan atau menyatukan ide-ide yang terdapat pada bacaan untuk kemudian diterjemahkan ke dalam bahasa sendiri.

c. Guru membagi siswa dalam berkelompok kecil (3-5 siswa). d. Siswa berinteraksi dan berkolaborasi dengan teman satu grup untuk membahas isi catatan dari hasil catatan (talk). Dalam kegiatan ini mereka menggunakan bahasa dan kata-kata yang mereka buat sendiri untuk menyampaikan ide-ide dalam diskusi. Pemahaman dibangun melali interaksinya dalam diskusi. Diskusi diharapkan dapat menghasilkan solusi atas soal yang diberikan.

e. Dari hasil diskusi, peserta didik secara individu merumuskan pengetahuan berupa jawaban atas soal (berisi landasan dan keterkaitan konsep, metode, dan solusi) dalam bentuk tulisan (write) dengan bahasanya sendiri. Pada tulisan itu, peserta didik menghubungkan ide0ide yang diperolehnya melalui diskusi.

f. Perwakilan kelompok menyajikan hasil diksusi kelompok, sedangkan kelompok lain diminta memberikan tanggapan.

g. Kegiatan akhir pembelajaran adalah membuat refleksi dan kesimpulan atas materi yang dipelajari. Sebelum itu, dipilih beberapa atau satu orang peserta didik sebagai perwakilan kelompok untuk menyajikan jawabannya, sedangkan kelompok lain diminta memberikan tanggapan.

Dalam pembelajaran Think Talk Write (TTW) juga metode pembelajarannya menonjolkan aspek kecepatan siswa dalam beraktivitas (berpikir, berbicara, menulis, dan lain-lain). Teknik-teknik yang bisa digunakan sebagai pengantar pelaksanaan strategi think talk write dalam pembelajaran meliputi: (1) Diskusi, (2) Ceramah, (3) Resitasi (pemberian tugas), (4) Tanya jawab, dan (5) Penemuan.

\section{Berpikir Kritis}

Menurut Vincent Ruggiero (dalam Johnson, 2010:187) mengartikan berpikir kritis sebagai "segala aktivitas mental yang membantu merumuskan atau memecahkan masalah, membuat keputusan atau memenuhi keinginan untuk memahami". Sedangkan John Chaffe (dalam Johnson, 2010:187) mendefinisikan berpikir kritis sebagai berpikir untuk menyelidiki secara sistematis proses berpikir itu sendiri. Maksudnya tidak hanya memikirkan dengan sengaja, tetapi juga meneliti bagaimana kita dan orang lain menggunakan bukti dan logika.

Menurut Rudinow dan Barry (dalam Dennis K. Filsaime, 2008:57), berpikir kritis adalah sebuah proses yang menekankan sebuah basis kepercayaan-kepercayaan yang logis dan rasional, dan memberikan serangkaian standard an prosedur untuk menganalisis, mrnguji dan mengevaluasi. Senada dengan Rudinow dan Barry, Scriven dan Paul (dalam Dennis K. Filsaime, 2008:56), juga memandang berpikir kritis sebagai proses disiplin cerdas 
dari konseptualisasi, penerapan, analisis, sintesis, dan evaluasi aktif dan berketerampilan yang dikumpulkan dari, atau dihasilkan oleh, observasi, pengalaman, refleksi, penalaran, atau komunikasi sebagai sebuah penuntun menuju kepercayaan dan aksi. Selain itu, berpikir kritis juga telah didefinisikan sebagai "berpikir" yang memiliki maksud, masuk akal, dan berorientasi tujuan" dan "kecakapan untuk menganalisis sesuatu informasi dan ideide secara hati-hati dan logis dari berbagai macam perspektif".

Menurut Ennis (dalam Sapriya, 2009:144) bahwa berpikir kritis merupakan istilah yang digunakan untuk suatu aktivitas reflektif untuk mencapai tujuan yang melakukan identifikasi lima kunci unsur berpikir kritis, yakni, "praktis, reflektif, rasional, terpecaya, dan berupa tindakan". Dengan didasari oleh pemikiran inilah, ia merumuskan suatu definisi bahwa berpikir kritis merupakan aktivitas berpikir secara reflektif dan rasional yang difokuskan pada penentuan apa yang harus diyakini atau dilakukan. Definisi ini lebih menekankan pada bagaimana membuat keputusan atau pertimbangan.

Salah satu tujuan utama persekolahan adalah meningkatkan kemampuan siswa untuk berpikir kritis, membuat keputusan rasional tentang apa yang diperbuat atau diyakini menurut Ennis dan Hitchcock (dalam Nur, 2004:61). Keterampilan dalam berpikir kritis paling baik dicapai bila berhubungan dengan topik-topik yang dikenal siswa yang paling penting tujuan pengajaran berpikir kritis adalah menciptakan suatu semangat berpikir kritis yang mendorong siswa mempertanyakan apa yang mereka dengar dan mengkaji pikiran mereka sendiri untuk memastikan tidak terjadi logika yang tidak konsisten atau keliru menurut Norris (dalam Nur, 2004:62). Pendapat tersebut diperkuat oleh Dennis (2007:88) bahwa daya berpikir kritis bisa ditingkatkan melalui bertanya kritis.

Dari beberapa pengertian kemampuan berpikir kritis diatas, dapat ditegaskan bahwa berpikir kritis adalah cara berpikir secara reflektif, sistematis dan beralasan dalam menganalisis atau mengevaluasi berbagai informasi dalam mengambil tindakan. Selain itu, keterampilan berpikir dengan konsep yang matang dengan mengungkapkan ideide dan mempertanyakan secara logis segala sesuatu yang dianggap tidak tepat untuk difokuskan pada penentuan apa yang harus diyakini atau dilakukan.

Menurut Ennis (dalam Hassoubah, 2007), berpikir kritis adalah berpikir secara beralasan dan reflektif dengan menekankan pada pembuatan keputusan tentang apa yang harus dipercayai atau dilakukan. Oleh karena itu, indikator kemampuan berpikir kritis dapat diturunkan dari aktivitas siswa sebagai berikut: (1) Mencari pernyataan yang jelas dari setiap pertanyaan, (2) Mencari alasan, (3) Berusaha mengetahui informasi dengan baik, (4) Memakai sumber yang memiliki kredibilitas dan menyebutkannya, (5) Memperhatikan situasi dan kondisi secara keseluruhan, (6) Berusaha tetap relevan dengan ide utama, (7) Mengingat kepentingan yang asli dan mendasar, (8) Mencari alternatif, (9) Bersikap dan berpikir terbuka, (10) Mengambil posisi ketika ada bukti yang cukup untuk melakukan sesuatu, (11) Mencari penjelasan sebanyak mungkin apabila memungkinkan, (12) Bersikap secara sistematis dan teratur dengan bagian-bagian dari keseluruhan masalah.

\section{METODE}

Penelitian ini merupakan penelitian kuantitatif dengan jenis penelitian pengembangan, yang Mengembangkan Perangkat Pembelajaran Model Think Talk Write pada Subtema Hidup Rukun untuk Meningkatkan Kemampuan Berpikir Kritis Siswa Kelas V Sekolah Dasar. Hasil dari pengembangan perangkat ini diimplementasikan untuk mendapatkan deskripsi proses pembelajaran dan hasil peningkatan kemampuan berpikir kritis siswa.

Subjek penelitian adalah perangkat pembelajaran subtema hidup rukun yang dikembangkan terdiri atas Rencana Pelaksanaan Pembelajaran (RPP), Bahan Ajar Siswa (BAS), Lembar Kerja Siswa (LKS), dan Tes Kemampuan Berpikir Kritis. Sedangkan objek untuk uji coba perangkat pembelajaran adalah kelas VA dengan jumlah 35 siswa sebagai kelas normal dan kelas VB dengan jumlah 35 siswa sebagai kelas eksperimen di SDN Wonocolo II Sidoarjo.

Model pengembangan perangkat pembelajaran yang digunakan dalam penelitian ini terdiri atas tiga tahapan yaitu define (pendefinisian), design (perangcangan), dan develop (pengebangan) yang diadaptasi dari Four D-model yang dikemukakan oleh Thiagarajan (1947:5-8). Model ini dipilih karena sistematis dan cocok untuk mengembangkan perangkat pembelajaran. Penelitian ini ditujukan untuk pengembangan perangkat di mana setelah tahap pengembangan dihasilkan produk berupa perangkat yang layak.

Instrumen penelitian merupakan alat yang menghasilkan informasi yang objektif suatu alat untuk menjaring data atau alat pengukuran untuk menghasilkan informasi yang objektif dan dapat diberikan dalam bentuk kata-kata maupun angka-angka. Instrumen yang dikembangkan dalam penelitian ini meliputi: (1) Lembar Validasi RPP; (2) Lembar Validasi Bahan Ajar Siswa (BAS); (3) Lembar Validasi LKS; (4) Lembar Validasi Tes Kemampuan Berpikir Kritis; (5) Lembar Observasi 
Keterlaksanaan RPP, (6) Lembar Observasi Aktivitas Siswa; dan (7) Lembar Angket Respon Siswa.

Data dalam penelitian ini didapatkan melalui teknik pengumpulan data sebagai berikut:

1. Validasi

Metode yang digunakan untuk mengetahui kelayakan perangkat pembelajaran yang dikembangkan. Penilaian dilakukan oleh para pakar dan praktisi di bidang pendidikan dengan menggunakan lembar validasi diantaranya: kebenaran isi RPP, LKS, tingkat keterbacaan Bahan Ajar Siswa (BAS), dan validasi tingkat kesulitan BAS dalam pembelajaran.

2. Observasi

Observasi dilakukan untuk mengumpulkan data yang berkaitan dengan perilaku yakni data tentang keterlaksanaan RPP dan aktivitas siswa dengan menggunakan instrumen berupa lembar pengamatan observasi. Data tentang keterlaksanaan RPP dan aktivitas siswa diambil melalui pengamatan yang dilakukan oleh observer dan diisikan dalam format yang telah dikembangkan oleh peneliti.

3. Pemberian Tes

Tes pada lembar penilaian diberikan kepada siswa sebelum proses pembelajaran (Pre-test) dan sesudah proses pembelajaran (Post-test). Tes diberikan untuk mengetahui sejauh mana tiap soal mampu mengukur kemampuan berpikir kritis siswa setelah proses pembelajaran yang menggunakan model pembelajaran Think Talk Write pada subtema hidup rukun, perlu dicari sensitivitas butir soal.

4. Pemberian Angket

Lembar pengamatan berupa angket diberikan kepada siswa setelah kegiatan pembelajaran selesai. Pemberian angket dimaksudkan untuk mengumpulkan data tentang respon siswa terhadap pembelajaran dengan menggunakan model Think Talk Write pada subtema hidup rukun.

Analisis data dalam penelitian ini menggunakan analisis data deskriptif kualititatif. Data yang terkumpul dari penelitian dianalisis menggunakan statistik deskriptif kualitatif dan hasil pengamatan terhadap pembelajaran yang menggunakan model pembelajaran Think Talk Write, aktivitas siswa, dan pemahaman konsep siswa (tes hasil kemampuan beripikir kritis). Hasil analisis ini kemudian akan dideskripsikan secara kualitatif.

Teknik analisis data yang digunakan sebagai berikut: (1) Analisis Kelayakan Perangkat pembelajaran, (2) Analisis Kebenaran isi LKS, (3) Analisis Tingkat Keterbacaan Bahan Ajar Siswa, (4) Analisis Tingkat
Kesulitan Bahan Ajar Siswa, (5) Analisis Keterlaksanaan RPP, (6) Analisis Aktivitas Siswa, dan (7) Analisis Respon Siswa.

\section{HASIL DAN PEMBAHASAN}

Kualitas perangkat pembelajaran ditinjau dari validitas perangkat, yaitu validasi RPP, validasi Bahan Ajar Siswa (BAS), validasi LKS, dan validasi Lembar Tes Kemampuan Berpikir Kritis Siswa. Perangkat pembelajaran yang telah dikembangkan kemudian divalidasi oleh 2 orang pakar/ahli. Perangkat pembelajaran yang dikembangkan telah dinyatakan valid/layak untuk digunakan dalam proses belajar mengajar pada kelas $\mathrm{V}$ Sekolah Dasar. Sebagaimana dikemukakan Reigeluth (dalam Prawiradilaga, 2008:28) yang menyatakan bahwa pengembangan pembelajaran merupakan proses pelaksanaan di lapangan dari apa yang telah diselesaikan dalam desain yang merupakan kisi-kisi (blueprint) yang masih harus divalidasikan ketepatannya.

Berdasarkan analisis data pada BAB IV, dapat diketahui bahwa hasil efektivitas perangkat pembelajaran dapat dilihat dari empat aspek, meliputi: keterlaksanaan RPP, aktivitas siswa, respon siswa dan hasil tes kemampuan berpikir kritis siswa. Keempat aspek tersebut dapat dinilai melalui ujicoba yang dilakukan terhadap 35 siswa kelas VA dan 35 siswa kelas VB SDN Wonocolo II Sidoarjo yang diamati oleh dua orang pengamat.

1. Keterlaksanaan RPP yang dicapai pada uji oba termasuk dalam kriteria baik. Keterlaksanaan RPP didasarkan pada skenario pengelolaan kegiatan belajar megajar dan suasana kelas. Pengelolaan KBM, meliputi: pendahuluan, kegiatan inti, dan penutup. Langkah-langkah pembelajaran yang dilakukan guru sudah sesuai dengan sintaks model pembelajaran Think Talk Write (TTW) yang dimana model pembelajaran tersebut sesuai untuk mengajarkan kemampuan berpikir kritis karena di dalam pengertian "Think" itu sendiri sudah mengandung proses berpikir ketika kegiatan belajar mengajar berlangsung.

Hasil penilaian pada keterlaksanaan RPP menunjukkan bahwa pelaksanaan pembelajaran di kelas kontrol dengan menggunakan model Think Talk Write melalui kegiatan ujicoba berkategori baik. Diperoleh skor persentase untuk pertemuan pertama pada kelas kontrol sebesar $72.3 \%$. Sedangkan pada pertemuan kedua mengalami kenaikan dengan persentasi $77.8 \%$. Sedangkan ujicoba pada kelas eksperimen diperoleh skor persentase untuk kegiatan pembelajaran pada pertemuan pertama sebesar $80.6 \%$ dan mengalami kenaikan pada pertemuan kedua dengan persentase $87.5 \%$. Maka, dapat disimpulkan 
bahwa keterlaksanaan RPP pada penerapan perangkat pembelajaran dengan menggunakan model Think Talk Write dikategorikan terlaksana sangat baik.

2. Akvititas siswa diamati dan dinilai selama proses pembelajaran berlangsung. Hasil penilaian pengamat dapat dilihat pada diagram 1 berikut:

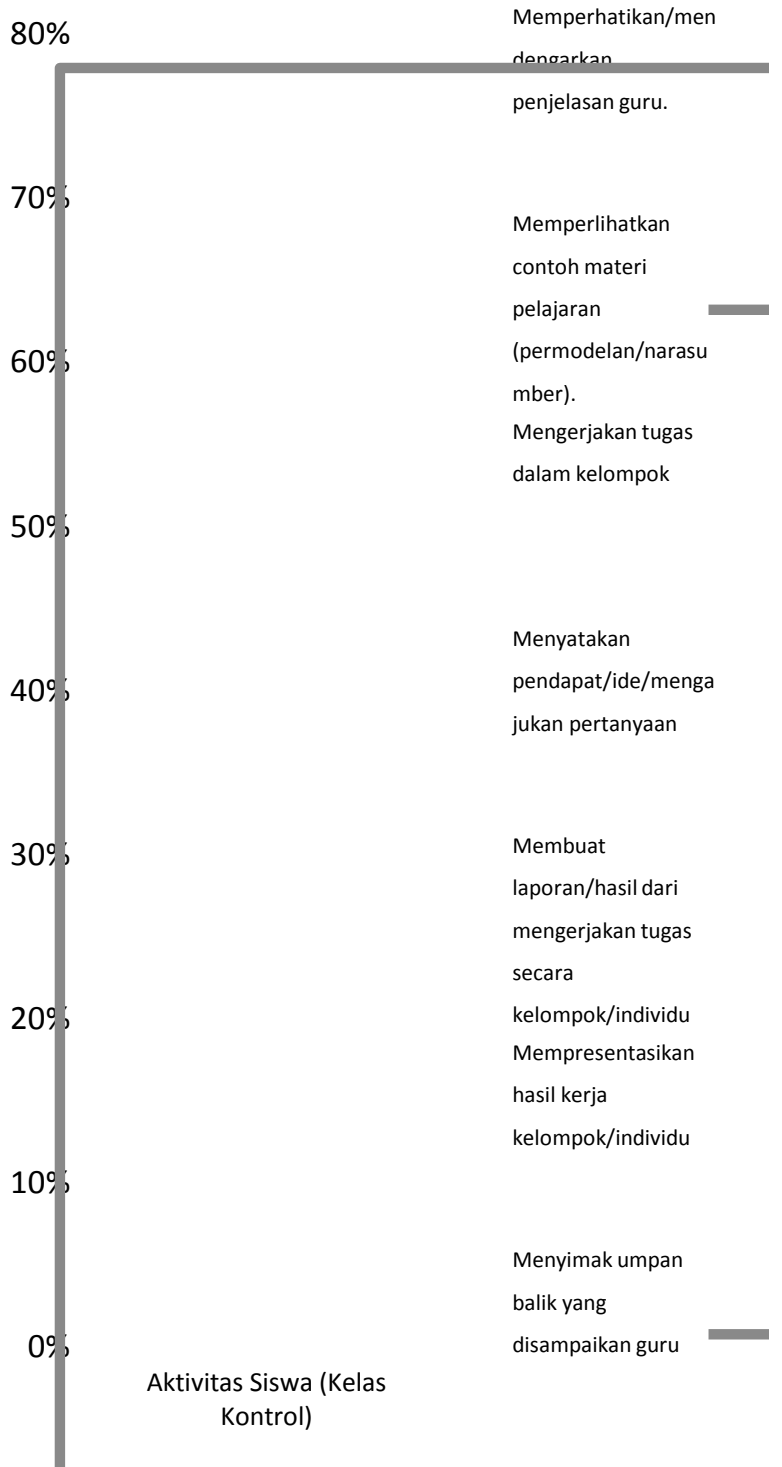

Diagram 1. Aktivitas Siswa Kelas Kontrol

Aktivitas siswa pada ujicoba kelas kontrol sebagaimana disajikan pada diagram 1 menunjukkan bahwa aktivitas paling menonjol dalam pembelajaran adalah memperhatikan/mendengarkan penjelasan guru dan menyimak umpan balik yang disampaikan guru, yakni sebesar $70 \%$ sedangkan aktivitas terendah adalah aktivitas yang tidak relevan (membuat gaduh), yakni sebesar 37,5\%. Sedangkan hasil rangkuman perhitungan aktivitas siswa kelas eksperimen disajikan pada diagram 2 berikut.

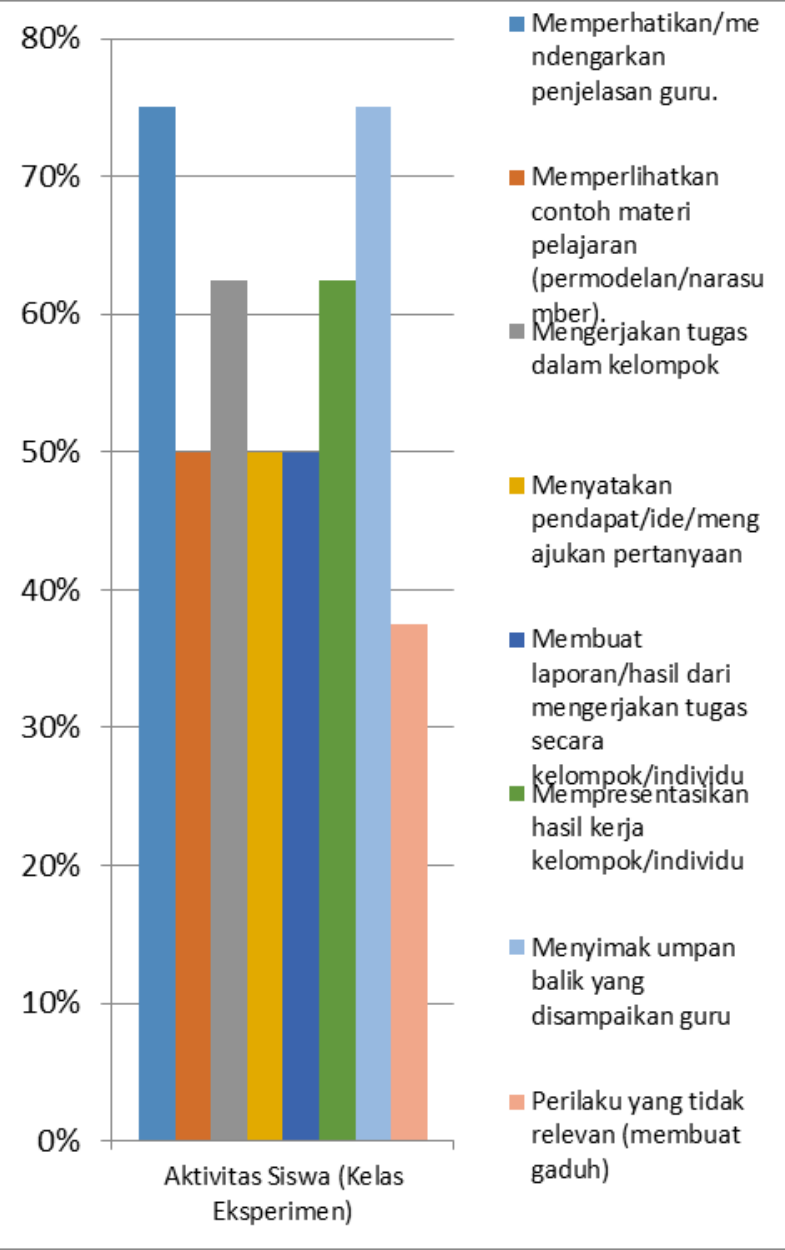

Diagram 2. Aktivitas Siswa Kelas Eksperimen

Aktivitas siswa pada ujicoba kelas eksperimen sebagaimana disajikan pada diagram 2 menunjukkan bahwa aktivitas paling menonjol dalam pembelajaran adalah Mengerjakan tugas dalam kelompok, yakni sebesar $75 \%$ sedangkan aktivitas terendah adalah aktivitas yang tidak relevan (membuat gaduh), yakni sebesar $37,5 \%$.

3. Respon siswa ditampung menggunakan angket yang diisi setelah pembelajaran selesai dilaksanakan. Tingginya respon positif siswa untuk mengikuti pembelajaran menggunakan dengan menggunakan model Think Talk Write (TTW) dikarenakan siswa dapat mengkontruksi pengetahuannya sendiri kemudian dikaitkan dengan materi yang diperoleh siswa. Hal ini berarti bahwa siswa merasa senang terhadap pembelajaran hari ini mengenai materi pelajaran, suasana belajar, dan cara guru mengajar. Hasil ini menunjukkan bahwa pembelajaran model Think Talk Write (TTW) untuk mengajarkan kemampuan berpikir kritis yang dilaksanakan dengan menggunakan perangkat pembelajaran yang dikembangkan oleh 
peneliti mendapat respon sangat positif dari para siswa karena hasil persentase respon siswa secara keseluruhan berada di atas $80 \%$. Respon positif siswa menunjukkan bahwa siswa antusias dengan pembelajaran yang disajikan.

4. Hasil tes kemampuan berpikir kritis siswa pada kelas kontrol dan kelas eksperimen menunjukkan perbedaan yang signifikan. Penilaian pretest pada ujicoba 1 di kelas kontrol siswa yang tuntas secara individu ada 19 siswa dan 16 siswa lainnya tidak tuntas dengan rata-rata kelas 69,6. Sedangkan ketuntasan klasikal pretest siswa yang tuntas dengan persentase $54,3 \%$. Sedangkan posttest pada uji coba 1 di kelas kontrol siswa yang tuntas secara individu ada 21 siswa dan 14 siswa lainnya tidak tuntas dengan rata-rata kelas 73,6 dengan presentase $60 \%$.

Sedangkan penilaian pretest pada ujicoba 2 di kelas eksperimen siswa yang tuntas secara individu ada 21 siswa dan 14 siswa lainnya tidak tuntas dengan ratarata kelas 69,7. Sedangkan ketuntasan klasikal pretest siswa yang tuntas dengan persentase $60 \%$. Sedangkan posttest pada ujicoba 2 di kelas eksperimen siswa yang tuntas secara individu ada 23 siswa dan 13 siswa lainnya tidak tuntas dengan rata-rata kelas 85,6 dengan presentase $65,7 \%$. Diperoleh pula hasil ketuntasan indikator kemampuan berpikir kritis siswa dengan ratarata $98 \%$ yang berarti bahwa siswa sudah tuntas secara klasikal. Sehingga dapat disimpulkan bahwa perbedaan nilai rata-rata pada kelas kontrol dan kelas eksperimen tersebut dapat dijadikan salah satu bukti bahwa pembelajaran dengan menggunakan model Think Talk Write (TTW) lebih baik/efektif daripada menggunakan pembelajaran konvensional. Hal tersebut menunjukkan bahwa terdapat perbedaan yang sangat signifikan.

Berdasarkan analisis data uji normalitas pada BAB IV, dapat diketahui bahwa nilai pretest pada kelas kontrol dan eksperimen analisis data menunjukkan bahwa nilai signifikasi pada kelas kontrol sebesar 0.200 dan pada kelas eksperimen sebesar 0.067. Kedua kelompok tersebut memiliki nilai signifikasi > 0,05 atau $>5 \%$.

Sedangkan hasil nilai posttest pada kelas kontrol dan kelas eksperimen analisis data menunjukkan bahwa nilai signifikansi pada kelas kontrol sebesar 0,200 dan pada kelas eksperimen sebesar 0,163. Kedua kelompok tersebut memiliki nilai signifikansi lebih besar dari nilai batas yaitu 0,05 . Sehingga nilai pretest dan posttest pada kelas kontrol dan kelas eksperimen dapat disimpulkan bahwa data berdistribusi normal.
Pada uji homogenitas digunakan uji F. Uji $F$ dilakukan dengan cara membandingkan nilai signifikansi dari varians. Hasil nilai pretest pada kelas kontrol dan eksperimen diketahui nilai signifikansi sebesar 0.154. Pada hasil nilai posttest kelas kontrol dan kelas eksperimen memiliki nilai signifikansi sebesar 0,52. Pada hasil pretest dan posttest kelas kontrol dan kelas eksperimen memiliki nilai signifikansi lebih besar dari nilai batas yaitu 0,05 . Sehingga dapat disimpulkan bahwa data baik pada kelas kontrol dan kelas eksperimen bersifat homogen.

Kemudian dengan melihat hasil uji Independent Sample T-test dapat diketahui bahwa data berdistribusi normal dan homogen. Kemudian peneliti melanjutkan untuk melakukan uji t. Pada uji beda hasil belajar pretest di kelas kontrol dan kelas eksperimen hasil nilai signifikansi adalah sebesar 0,956 sehingga lebih besar dari 0,05 maka Ha ditolak dan Ho diterima. Berdasarkan nilai signifikansi dalam Tabel 4.18 pada BAB IV, menunjukkan bahwa t-test for Equality of Means adalah $\mathrm{t}_{\text {hitung }}(0,52)>\mathrm{t}_{\text {tabel }}(1,667)$ pada df 68 dan $\mathrm{s}$ nilai signifikansi tersebut lebih kecil dari nilai $\alpha$ $(0,000<0,05)$, maka hipotesis nilai $(\mathrm{Ho})$ yang diujikan ditolak dan hipotesis alternative (Ha) diterima.

Jadi, dalam penelitian ini dapat disimpulkan bahwa ada pengaruh penggunaan pembelajaran model Think Talk Write (TTW) subtema hidup rukun pada kelas V Sekolah Dasar. Berdasarkan hasil di atas, maka telah terbukti bahwa hasil tes kemampuan berpikir kritis siswa yang mengikuti pembelajaran dengan menggunakan model Think Talk Write (kelas eksperimen) lebih baik secara signifikan daripada kelas kontrol. Keberhasilan pembelajaran dengan model Think Talk Write (TTW) untuk meningkatkan kemampuan berpikir kritis siswa dalam penelitian ini, perangkat pembelajaran dikembangkan sesuai prosedur dan perangkat yang dikembangkan divalidasi oleh validator/ahli.

\section{PENUTUP}

\section{Simpulan}

Berdasarkan dari hasil penelitian, maka dapat disimpulkan bahwa perangkat pembelajaran model Think Talk Write (TTW) yang dikembangkan yang mengacu pada model Four-D sebagai berikut:

1. Berdasarkan hasil uji validasi pengembangan perangkat pembelajaran model Think Talk Write (TTW) subtema hidup rukun telah dinyatakan memenuhi kelayakan/valid oleh dua validator/ahli. Dari hasil penelitian menunjukkan bahwa tes 
kemampuan berpikir kritis siswa pada subtema hidup rukun dapat diketahui adanya peningkatan nilai. Dengan demikian, dapat disimpulkan bahwa perangkat pembelajaran subtema hidup rukun dapat digunakan sebagai bahan ajar untuk meningkatkan kemampuan berpikir kritis siswa kelas V Sekolah Dasar.

2. Perangkat pembelajaran yang dikembangkan efektif untuk meningkatkan kemampuan berpikir kritis siswa. Terbukti dalam hasil analisis tes kemampuan berpikir kritis siswa yang menunjukkan adalah $t_{\text {hitung }}(0,52)>$ $\mathrm{t}_{\text {tabel }}(1,667)$ dengan taraf signifikansi $0,05 / 5 \%$. Dari uraian tersebut, dapat dijelaskan bahwa rata-rata nilai hasil tes siswa yang mengikuti pembelajaran model Think Talk Write (kelas eksperimen) memperoleh nilai lebih baik secara signifikansi daripada hasil tes siswa yang tidak mengikuti pembelajaran model Think Talk Write (kelas kontrol). Dengan demikian, pembelajaran model Think Talk Write (TTW) subtema hidup rukun efektif dalam meningkatkan kemampuan berpikir kritis siswa kelas V Sekolah Dasar.

\section{Saran}

Berdasarkan kesimpulan seperti yang dipaparkan di atas disarankan hal-hal sebagai berikut:

1. Pembelajaran dengan menggunakan model Think Talk Write (TTW) tergolong efektif dalam meningkatkan kemampuan berpikir kritis siswa. Oleh karena itu, guru sebaiknya menerapkan model pembelajaran Think Talk Write (TTW) pada materi ajar yang lain, agar siswa terbiasa dengan pembelajaran model tersebut.

2. Melalui model pembelajaran Think Talk Write (TTW) siswa dapat memperoleh informasi dengan mengkonstruksi pikirannya sendiri, bukan pemberian informasi langsung dari guru, sehingga dapat melatih siswa untuk berpikir lebih kritis. Oleh karena itu, guru sebaiknya mempunyai keterampilan/keahlian dalam menggunakan model pembelajaran.

\section{DAFTAR PUSTAKA}

Huda, Miftahul. (2012). Cooperative Learninga: Metode, Teknik, Struktur dan Model Terapan. Yogyakarta: Pustaka Belajar.

Filsaime, K. Dennis. (2008). Menguak Rahasia Berpikir Kritis dan Kreatif. Jakarta: Prestasi Pustaka.

Fisher, A. (2009). Berpikir Kritis. Diterjemahkan oleh Hadinata, B. Jakarta: Erlangga.

Griffiths, K. (2005). Personal coaching: A model for effective learning. Journal of Learning Design, $1(2), 55-65$.
Hamdayama, J. (2014). Model dan Metode Pembelajaran Kreatif dan Berkarakter. Bogor Ghalia Indonesia.

Hossoubah, Z. (2007). Developing Creative and Critical Thinking Skills (terjemahan). Bandung: Yayasan Nuansa Cendia.

Ibrahim, M. (2002). Pelatihan Terintegrasi Berbasis Kompetensi: Pengembangan Perangkat Pembelajaran. Surabaya: Direktorat Sekolah Llanjutan Tingkat Pertama Departemen Pendidikan Nasional.

Ibrahim, M. (2005). Seri Pembelajaran Inovatif Asesmen Berkelanjutan Konsep Dasar, Tahap Pengembangan dan Contohnya. Surabaya: UNESA University Press.

Johnson, Elaine B. (2010). Contextual Teaching \& Learning menjadikan Kegiatan Belajar Mengajar Mengasikkan dan Bermakna Bandung: Kaifa Learning.

Krulick, et, al. (2003). Teaching Mathematics in Middle School. A Practical Guide. United States of America: Pearson Education, Inc.

Nur, M., Wikandari, P. R. (2006). Pengajaran Berpusat Kepada Siswa dan Pendekatan Kontruktivis dalam Pengajaran. Surabaya: UNESA Pusat Sains dan Matematika Sekolah.

Sapriya. (2009). Pendidikan IPS Konsep dan Pembelajaran. Bandung: Remaja Rosdakarya.

Suryabrata. (2002). Psikologi Pendidikan. Yogyakarta: Universitas Gajah Mada.

Thiagarajan, S., Semmel, D. S., \& Semmel, M. I. (1974). Instructional Development for Training Teachers of Exceptional Children: A Sourcebook. Bloomington: Indiana University.

Zulkarnain. (2011). Model Kooperatif Think Talk Write untuk Meningkatkan Kemampuan Menulis Karangan Deskripsi dan Berpikir Kritis. Jurnal, Pascasarjana Universitas Pendidikan Indonesia. Vol: 2. 